\title{
Corporate Governance, Corporate Social Responsibility and Financial Performance, CGPI Award in Indonesia
}

\author{
Felita Fabiani, Ririn Breliastiti* \\ Bunda Mulia University \\ Jakarta, Indonesia \\ *rbreliastiti@bundamulia.ac.id
}

\begin{abstract}
This study aims to determine how the influence of Corporate Governance (CG) and Corporate Social Responsibility (CSR) on the company s financial performance. The Corporate Governance Perception Index (CGPI) ranking score is used to measure the CG mechanism, seventeen goals from Sustainable Development Goals (SDGs) are used to measure CSR, and Return on Assets (ROA) are used to measure financial performance. The sample used as many as 28 companies were following CGPI program and listed in Indonesia Stock Exchange. Descriptive statistical tests, classic assumption tests and hypothesis testing are the analytical methods used in this study. The findings in this study indicate that CG has an influence on the company's financial performance. By implementing good governance, companies tend to have higher values as well. With the Good CG, the company $s$ performance becomes more efficient so that the company has the opportunity to generate greater profits. The next finding is that the company $s$ financial performance is not influenced by CSR. This can be caused because in this study CSR is proxied using SDGs, where the application of SDGs as a basis for measurement in this research is still in transition so it has not yet impacted ROA because the duration of the year is still relatively new. The use of SGDs to measure CSR is a novelty of this study, while other studies usually use GRI as a measure of CSR. The relatively new SDGs implementation can be an alternative measurement for CSR which shows that the company s CSR activities are in line with the achievement of SGDs.
\end{abstract}

Keywords-corporate governance, corporate social responsibility, financial performance, CGPI

\section{INTRODUCTION}

Indonesia became one of the developing countries that experienced significant industrial growth. It was marked by the high number of growth of companies in Indonesia such as manufacturing and service companies. The success of a company in achieving its objectives can be assessed from the company s financial performance which is also used as a basis for decision making by internal parties as well as external parties [1].
Corporate Governance (CG) is a factor that can affect company performance. $\mathrm{CG}$ is defined as a principle that must be carried out by the company in terms of direction and control so that the company can achieve a balance between power and authority in order to provide accountability to shareholders. In early 2019 there were cases related to the application of CG, namely a violation of $\mathrm{CG}$ principles at PT Pertamina. In an indictment, the Managing Director of PT Pertamina was alleged to have ignored the investment procedures applicable at PT Pertamina and other investment provisions or guidelines in the Interest Participation (PI) of the Australian Basker Manta Gummy Block (BMG) in 2009 [2].

Corporate Social Responsibility (CSR) is the next factor that can affect company performance. CSR is a concept that suppresses corporate responsibility to the environment and surrounding communities. In addition to the pursuit of profit, companies must also pay attention and be involved in fulfilling the welfare of the community, as well as actively contributing to protecting the environment [3]. Unfortunately, in 2019 PT Pertamina was again exposed to a case of environmental degradation, namely the destruction of hundreds of hectares of coral reefs due to oil spills in the waters of Karawang, West Java [4].

\section{LITERATURE REVIEW}

\section{A. Corporate Governance $(C G)$}

CG was first introduced by the Cadbury Committee in 1992 which used the term in their report (Cadbury Report). According to Cadbury, CG directs and controls the company so that it can balance the power and authority possessed by the company [5]. CG is a system that can be applied to control and manage the company so that the company can create added value for all stakeholders [6].

\section{B. Corporate Governance Perception Index (CGPI)}

Evaluation of the implementation of Good Corporate Governance (GCG) in Indonesia is carried out by independent institutions, namely: Indonesian Institute for Corporate 
Governance (IICG). CGPI is a ranking and research program for implementing GCG in public companies in Indonesia managed by IICG. The objectives of conducting this research program (1) in terms of direction: by implementing quality GCG, it is possible to create added value for stakeholders, and will create sustainable business success, (2) in terms of scope: GCG practices and value added creation can meet three dimensions namely compliance, conformance and performance.

\section{Corporate Social Responsibility (CSR)}

CSR is integrated with the business that is run by the company, while still considering the interests of the stakeholders in the hope of providing benefits/ welfare for the community [6]. CSR concepts and practices today are no longer seen as a cost center but also as a corporate strategy that can spur and stabilize business growth in the long run. Therefore it is important to disclose CSR in the company as a form of reporting social responsibility to the community [7].

\section{Sustainability}

The three pillars of the concept of sustainability consist of social, economic and environmental-also known informally as people, profits and planet (triple bottom line). Working to meet the needs of the present without reducing the ability of future generations to meet their needs is the focus of sustainability. Sustainable development is the organizing principle to meet human development goals by maintaining equity, economic development, energy savings, ecological preservation and community participation. The expected outcome of sustainable development is a condition where living resources can be used to continue to meet human needs without destroying the stability and integrity of natural systems. Over the past ten years, there have been many studies that have raised the theme of sustainability [8-13]. This shows that many parties support sustainability.

\section{E. Sustainable Development Goals (SDGs)}

The concept of the SDGs was born at the Conference on Sustainable Development conducted by the United Nations in Rio de Jainero in 2012. The aim of the meeting was to obtain a universal shared goal that is able to maintain the balance of three dimensions of sustainable development: environmental, social and economic. The SDG has five main foundations in an effort to balance the three dimensions of sustainable development, namely people, planets, prosperity, partnerships and peace which together want to be achieved for the noble goal of 2030 in an effort to tackle climate change, achieve equality and reduce poverty [14].

\section{F. Company Performance}

Company performance can be assessed from financial and non-financial aspects as well. Financial aspects can be analyzed from financial statements (statement of financial possition, income statement, cash flow statement, etc.). While the nonfinancial aspects can be seen from customer satisfaction, employee loyalty, market share, the development of the company s business activities and so on. Companies must be able to take advantage of the strengths of the company and fix existing weaknesses. Performance measurement is very useful to assess the progress that has been achieved by the company and produce information that is very useful for management decision making and able to create the value of the company itself to stakeholders [3].

H1: Corporate Governance affects the company s financial performance.

H2: Corporate Social Responsibility Disclosure affects the company s financial performance.

\section{METHODS}

The research subjects are companies that won the CGPI Award which are listed on the Indonesia Stock Exchange (BEI) which runs the $\mathrm{CG}$ and CSR programs. Companies that won the CGPI Award are companies in Indonesia that are included in the Indonesia Most Trusted Companies category, which is an award event given by IICG in collaboration with SWA Magazine. This research is a causality research that aims to prove the possibility of a causal relationship. The independent variables are Corporate Governance and Corporate Social Responsibility, with the dependent variable is Corporate Financial Performance.

The study uses secondary data in the form of annual reports of companies winning the 2014-2017 CGPI Award and being listed on the Indonesia Stock Exchange. Information regarding the company's annual financial statements is collected from the official website of the Indonesia Stock Exchange. Information on the list of companies that won the CGPI Award from SWA Magazine.

Population is a listed company on the Indonesia Stock Exchange that won the CGPI Award in 2014-2017. The research method used in sample selection is to use purposive sampling. The criteria used as samples in this study are CGPI Award winning companies were listed on the IDX in 20142017 and earned a profit in 2014-2017.

Definition of variable operations show in table 1 below: 
TABLE I. DEFINITION OF VARIABLE OPERATIONS

\begin{tabular}{|c|c|c|}
\hline Variables & Definitions & Formulas \\
\hline $\mathrm{CG}$ & $\begin{array}{l}\text { CG is the principle that directs and controls the company so that it can balance the } \\
\text { power and authority possessed by the company. IICG defines GCG as the } \\
\text { structure, system and process used by company organs as an effort to } \\
\text { provide added value to the company in a sustainable manner over a } \\
\text { long period of time [15]. }\end{array}$ & $\begin{array}{l}\text { CGPI }=\sum \text { self assessment }+ \text { document }+ \\
\text { paper }+ \text { observation }\end{array}$ \\
\hline CSR & $\begin{array}{l}\text { CSR is a form of the company s seriousness to set aside a portion of the company s } \\
\text { wealth to reduce the negative impacts that may occur as a result of the company s } \\
\text { business activities and seek to maximize the positive impact of the company s } \\
\text { operations on all parties that are interested in the economic, social and environmental. } \\
\text { In principle, CSR is an ongoing commitment of companies to be responsible } \\
\text { economically, socially and environmentally or ecologically to the community, the } \\
\text { environment and stakeholders [1]. }\end{array}$ & $\begin{array}{l}\qquad \text { CSRIJ }=\frac{\sum x i j}{\sum n j} \\
\text { SGDs }= \\
\text { CSRIJ = Disclosure of the Corporate Social } \\
\text { Responsibility Index of the company J. } \\
\sum \mathrm{Xij}=\text { total CSR scores disclosed } \\
\mathrm{Nj}=\text { Total score of } 17 \text { disclosure items from } \\
\text { total SDGs objectives } \\
{[16]}\end{array}$ \\
\hline $\begin{array}{l}\text { Company } \mathrm{s} \\
\text { financial } \\
\text { performance }\end{array}$ & $\begin{array}{l}\text { The company s financial performance is the work performance achieved by the } \\
\text { company in a certain period and reflected in the company s financial statements so } \\
\text { that the performance that has been carried out by management can be evaluated and } \\
\text { can be improved for the following year [17] }\end{array}$ & $\begin{array}{l}\text { ROA }=\frac{E A T}{T A} \times 100 \% \\
\text { EAT }=\text { Earning After Tax } \\
\text { TA = Total Asset }\end{array}$ \\
\hline
\end{tabular}

\section{RESULTS AND DISCUSSION}

\section{A. Results}

TABLE II. PURPOSIVE SAMPLING

\begin{tabular}{|l|l|l|l|}
\hline No. & \multicolumn{1}{|c|}{ Criteria } & \multicolumn{1}{|c|}{$\begin{array}{l}\text { Number of } \\
\text { Companies }\end{array}$} & $\begin{array}{c}\text { Firm } \\
\text { Years }\end{array}$ \\
\hline 1. & $\begin{array}{l}\text { CGPI Award winning } \\
\text { companies were listed on the } \\
\text { IDX during 2014-2017 }\end{array}$ & 36 & \\
\hline $\begin{array}{l}\text { Companies that did not make a } \\
\text { profit in 2014-2017 }\end{array}$ & $(8)$ & \\
\hline 2 & Total Companies sampled & 28 & 112 \\
\hline & Total sample & & \\
\hline
\end{tabular}

TABLE III. DESCRIPTIVE STATISTICS

\begin{tabular}{|l|l|l|l|l|l|}
\hline & N & Minimum & Maximum & Mean & $\begin{array}{c}\text { Std. } \\
\text { Deviation }\end{array}$ \\
\hline ROA & 112 & 0.008 & 0.759 & 0.095 & 0.110 \\
\hline CGPI & 112 & 0.000 & 98.310 & 46.829 & 40.361 \\
\hline SDGs & 112 & 0.235 & 0.882 & 0.660 & 0.129 \\
\hline
\end{tabular}

Source: Data processed

TABLE IV. T-TEST

\begin{tabular}{|l|l|l|}
\hline \multicolumn{1}{|c|}{ Model } & \multicolumn{1}{|c|}{ Coefficients } & \multicolumn{1}{c|}{ Prob. } \\
\hline (Constant) & & 0.553 \\
& & $(0.322)$ \\
\hline CGPI & 0.206 & $0.034^{*}$ \\
& & $(0.001)$ \\
\hline SDGs & -0.093 & 0.333 \\
& & $(0.406)$ \\
\hline
\end{tabular}

Source: Data processed

\section{B. Discussion}

1) The influence of $C G$ on company financial performance: $\mathrm{CG}$ is proven to affect financial performance. The results of this study are in line with studies stating that CG can improve company performance $[18,19]$. There are two studies which state that CG positively influences company value $[15,20]$. Companies that implement better corporate governance tend to have higher values. Subsequent research states that CGPI has a significant positive effect on financial performance [7,17]. With the existence of GCG the company s performance becomes much more efficient so that the company has the opportunity to produce greater profits. In other words CG functions to reduce or reduce agency costs (Agency Cost) [21] and improve company performance. This research is also supported by two previous studies which stated that the higher the implementation of Corporate Governance as measured by CGPI, the higher the level of corporate compliance and produce good company performance $[22,23]$. Companies with good CG will have better operational performance. Risks and capital costs will be minimized through the performance of active managers, thereby increasing company profitability. Companies that participate in the CGPI rating always increase in quality and quantity every year, that means awareness about CG has improved. The CGPI variable has a significant effect on profitability [24]. This can be caused by the CGPI score being published to the general public so that the company $\mathrm{s}$ credibility increases, then the value of sales will increase and will have an impact on increasing company profits. Tests in this study prove that $\mathrm{CG}$ affects the company $\mathrm{s}$ financial performance. With the research program conducted by IICG 
together with SWA Magazine, it can be seen how reliable CG is in a company. GCG can improve supervision and control of the company, so that the possibility of misuse of assets or other losses can be minimized. So the more supervision, complete documents and controls in the company can influence the company s financial performance itself.

The results of this research reinforce previous research conducted on the Indonesia Stock Exchange for 2014 data. The GCG mechanism has an influence on the company s financial performance and represent positive and significant effects. the board of commissioners plays a very important role. Companies that have a large number of commissioners will provide strong supervision of management in an effort to improve company performance. The board of commissioners has a large role especially in relation to the oversight function of the implementation of the policy of the board of directors.

Independent commissioners play a role in minimizing agency problems that arise between shareholders and the board of directors. Independent commissioners are expected to carry out their functions to oversee the performance of the directors so that the resulting performance is in accordance with the concerns of shareholders.

In addition to running the GCG mechanism, companies that are audited by public accountants will benefit in the form of input on management performance in accordance with company conditions. Opinions issued by public accountants can be the basis for companies to try to improve performance and maintain their survival [19].

2) The influence of CSR on company financial performance: The results of this research represent that CSR does not affect the company s financial performance. This finding is not in line with previous research which says that CSR has a positive and significant effect on a company $s$ financial performance $[24,19]$. The results of this research are also not in accordance with research which says that CSR disclosure has a positive effect on ROA [25], besides that there are studies that say that CSR has a significant influence on Return On Assets [26-28]. The results of this study are also not in line with research which states that there is a significant positive relationship between CSR disclosure and Islamic bank financial performance [29]. Other research states that CSR has a negative effect on a company $s$ financial performance [3].

Testing in this study proves that CSR has no effect on the company s financial performance. This can be caused because in this study CSR is proxied using SDGs, where the application of SDGs as a basis for measurement in this study only took effect in 2015 and is still in transition so the impact on ROA is still not felt because the duration of the year is still relatively new.

\section{CONCLUSIONS}

The partial test results show that CG has an effect on the company s financial performance, while CSR has no effect on the company s financial performance. It is recommended for companies to be able to increase the value of CGPI by fulfilling each of the CGPI assessment criteria, namely by conducting a self assessment on the quality of $\mathrm{CG}$ implementation, completeness of documents related to CG implementation, preparing papers and readiness when observing, because in this study it is evident that companies that have a good CGPI will affect the company s financial performance. This research period is only four years (2014-2017) which caused the impact of the SDGs not yet felt, so it is expected that in subsequent studies it can use a longer period, because CSR activities will have an impact when applied for a longer period duration. In addition, this study uses two independent variables namely CG and CSR, this causes $\mathrm{R}^{2}$ to be small, so there are still many other factors that can give impact to the company $\mathrm{s}$ financial performance, such as earnings quality, leverage, capital structure, board gender diversity, complex state ownership, corporate governance structure and others [30-32].

\section{REFERENCES}

[1] Melawati, Nurlaela, S.,and E.M. Wahyuningsih, "Pengaruh Good Corporate Governance, CSR, dan Ukuran Perusahaan Terhadap Kinerja Perusahaan," Journal of Economic and Economic Education, Vol. 4, No. 2, pp. 210-226, 2016.

[2] A. Gabrillin, Menurut Jaksa, Karen Agustiawan Melanggar Prinsip Good Governance. Kompas.com. 14 Februari 2019. https://nasional.kompas.com/ read/2019/02 /14/10510941/menurutjaksa-karen-agustiawan-melanggar-prinsip-good-governance. Downloaded 16 September 2019.

[3] L. Awaluddin, Ratusan Hektare Terumbu Karang Rusak Tercemar Tumpahan Minyak Pertamina. Detik.com. 8 Agustus 2019. https://news.detik.com/berita-jawa-barat/d-4657267/ratusan-hektareterumbu-karang-rusak-tercemar-tumpahan-minyakpertamina?_ga=2.232198495.1978223964.1568615469-1430164483 .1542783310 . Downloaded 16 September 2019.

[4] A. Sutedi, Good Corporate Governance, Jakarta: Sinar Grafika, 2011

[5] M.A. Daniri, Lead by GCG. Jakarta: Gagas Bisnis, 2014.

[6] A.S. Lindawati and M.E. Puspita, "Corporate Social Responsibility: implikasi stakeholder dan legitimacy GAP dalam peningkatan kinerja perusahaan," Jurnal Akuntansi Multiparadigma JAMAL, Volume 6 Nomor 1, pp. 1-174, 2015.

[7] N. Hadi, Corporate Social Responsibility, Yogyakarta: Graha Ilmu, 2011 .

[8] Ishartono and S.T. Raharjo, "Sustainable Development Goals (SDGs) dan Pengentasan Kemiskinan," Social Work Jurnal, Vol. 6, No. 2, pp. $154-272,2015$.

[9] M.K. Indarti and L. Extaliyus, "Pengaruh Corporate Governance Preception Index (CGPI), Struktur Kepemilikan dan ukuran Perusahaan Terhadap Kinerja Keuangan,” Jurnal Bisnis dan Ekonomi (JBE) Vol. 20, No. 2, pp. $171-183,2013$.

[10] J. Bebbington and J. Unerman, "Achieving the United Nations Sustainable Development Goals: An enabling role for accounting research," Accounting, Auditing \& Accountability Journal, Vol. 31 Issue: 1, pp. 2-24, 2018.

[11] A. Farhan, S.N. Obaid and H. Azlan, "Corporate governance effect on firms performance - evidence from the UAE," Journal of Economic and Administrative Sciences, Vol. 33 Issue:1, pp. 66-80, 2017. 
[12] F. Siagian, S.V. Siregar and Y. Rahadian, "Corporate governance, reporting quality, and firm value: evidence from Indonesia," The international journal of business in society, Vol. 14 Iss 4, pp. 453-466, 2013.

[13] P.W. Iswara, "Corporate Governance dan Kinerja Perusahaan,” Jurnal Akuntansi, Ekonomi dan Manajemen Bisnis vol. 2, no. 2, pp. 121-131, 2014.

[14] C. Nuswandari, "Pengaruh Corporate Governance Perception Index Terhadap Kinerja Perusahaan Pada Perusahaan yang terdaftar di Bursa Efek," Jurnal Bisnis dan Ekonomi (JBE), Vol. 16, No.2, pp. 70 - 84, 2009.

[15] M.C. Jensen and W.H. Meckling, "Theory of the Firm: Managerial Behavior, Agency Costs and Ownership Structure," Journal of Financial Economics, Vol. 3, No. 4, pp. 305-360, 1976.

[16] I.M. Puniayasa and N. Triaryati, "Pengaruh Good Corporate Governance, Struktur Kepemilikan dan Modal Intelektual Terhadap Kinerja Keuangan Perusahaan yang Masuk Dalam Indeks CGPI," EJurnal Manajemen Unud, Vol. 5, No.8, pp. 5304-5332, 2016.

[17] A. Wahyudin and B. Solikhah, "Corporate governance implementation rating in Indonesia and its effects on financial performance," The International Journal of Business in Society, Vol. 17 Issue: 2, pp. 250265, 2017.

[18] I.M. Sholihah and E. Nuraina, "Pengaruh Corporate Social Responsibility terhadap Kinerja Perusahaan," Jurnal Akuntansi dan Pendidikan, Volume 2, Nomor 2, 2013.

[19] A.A. Candrayanthi and I.D. Saputra, "Pengaruh pengungkapan Corporate Social Responsibility Terhadap Kinerja Perusahaan,” E-Jurnal Akuntansi Universitas Udayana 4.1, pp. 141-158, 2013.

[20] E. Platonova, M. Asutay, R. Dixon and S. Mohammad, "The Impact of Corporate Social Responsibility Disclosure on Financial Performance: Evidence from the GCC Islamic Banking Sector,” J Bus Ethics, pp. 451471, 2016.

[21] C. Filemon and A. Krisnawati, "Pengaruh Corporate Social Responsibility Disclosure Terhadap Return On Assets Pada Perusahaan Telekomunikasi yang Terdaftar di Bursa Efek Indonesia," Jurnal Manajemen Indonesia, Vol. 14, No. 3. 2014.
[22] N. Akbar, B. Rikumahu and A. Firli, "Pengaruh Corporate Social responsibility Terhadap Kinerja Keuangan," e-Proceeding of Management, Vol. 3, No. 2, pp. 977, 2016.

[23] I.A. Rahmawati, B. Rikumahu and V.J. Dillak, "Pengaruh Dewan Direksi, Dewan Komisaris, Komite Audit dan Corporate Social Responsibility Terhadap Kinerja Keuangan Perusahaan," Jurnal Akuntansi \& Ekonomi FE. UN PGRI Kediri Vol. 2, No. 2, 2017.

[24] A. Charles, R. Dang and E. Redor, "Board Gender Diversity and Firm Financial Performance: a Quantile Regression Analysis," International Corporate Governance and Regulation Advances in Financial Economics, Vol. 20, pp. 15-55, 2019.

[25] E. Liljeblom, B. Maury and A. Hörhammer, "Complex state ownership, competition, and firm performance - Russian evidence," International Journal of Emerging Markets, 2019.

[26] L. Shao, "Dynamic study of corporate governance structure and firm performance in China Evidence from 2001-2015," Chinese Management Studies, Vol. 13, No.2, pp. 299-317, 2019.

[27] M. Mahrani and N. Soewarno, "The effect of good corporate governance mechanism and corporate social responsibility on financial performance with earnings management as mediating variable," Asian Journal of Accounting Research, Vol. 3, No. 1, pp. 41-60, 2018.

[28] A.A.A. Souza, M.F.R. Alves, N. Macini, L.O. Cezarino and L.B. Liboni, "Resilience for sustainability as an eco-capability. International Journal of Climate Change Strategies and Management. Vol.9 No.5, (2017). 581-599.

[29] M. Bradford, J.B. Earp and P.F. Williams, "Understanding sustainability for socially responsible investing and reporting," Journal of Capital Markets Studies, Vol. 1, No. 1, pp. 10-35, 2017.

[30] N.J. Hanson-Rasmussen and K.J. Lauver, "Environmental responsibility: millennial values and cultural dimensions," Journal of Global Responsibility, Vol. 9, No.1, pp. 6-20, 2018.

[31] P. Smart, S. Hemel, F. Lettice, R. Adams and S. Evans, "Preparadigmatic status of industrial sustainability: a systematic review," International Journal of Operations \& Production Management. Vol. 37 No. 10, pp. 1425-1450.

[32] P.P. Xu, E.H. Chan and Q.K. Qian, "Key performance indicators (KPI) for the sustainability of building energy efficiency retrofit (BEER) in hotel buildings in China. Facilities. Vol. 30 No. 9/10, (2012). 432-448. 